14. Beasley DW, Li L, Suderman MT, Barrett AD. Mouse neuroinvasive phenotype of West Nile virus strains varies depending upon virus genotype. Virology. 2002;296:17-23.

15. Berthet FX, Zeller HG, Drouet MT, Rauzier J, Digoutte JP, Deubel V. Extensive nucleotide changes and deletions within the envelope glycoprotein gene of Euro-African West Nile viruses. J Gen Virol. 1997;78:2293-7.

16. Lanciotti RS, Ebel GD, Deubel V, Kerst AJ, Murri S, Meyer R, et al. Complete genome sequences and phylogenetic analysis of West Nile virus strains isolated from the United States, Europe, and the Middle East. Virology. 2002;298:96-105.

17. Charrel RN, Brault AC, Gallian P, Lemasson JJ, Murgue B, Murri S, et al. Evolutionary relationship between Old World West Nile virus strains. Evidence for viral gene flow between Africa, the Middle East, and Europe. Virology. 2003;315:381-8.

18. Bakonyi T, Hubalek Z, Rudolf I, Nowotny N. Novel flavivirus or new lineage of West Nile virus, central Europe. Emerg Infect Dis. 2005;11:225-31.

19. Glávits R, Ferenczi E, Ivanics É, Bakonyi T, Mató T, Zarka P, et al. Occurrence of West Nile Fever in a circovirus infected goose flock in Hungary. Avian Pathol. 2005;34:408-14.

20. Ferenczi E, Rácz G, Faludi G, Czeglédi A, Mezey I, Berencsi G. Natural foci of classical and emerging viral zoonoses in Hungary. In: Berencsi G, Khan AS, Halouzka J, editors. Emerging biological threat. Amsterdam: IOS Press; 2005. p. 43-9.

21. Weissenböck H, Kolodziejek J, Url A, Lussy H, Rebel-Bauder B, Nowotny N. Emergence of Usutu virus, an African mosquito-borne flavivirus of the Japanese encephalitis virus group, central Europe. Emerg Infect Dis. 2002;8:652-6.
22. Thompson JD, Gibson TJ, Plewniak F, Jeanmougin F, Higgins DG. The CLUSTAL_X windows interface: flexible strategies for multiple sequence alignment aided by quality analysis tools. Nucleic Acids Res. 1997;25:4876-82.

23. Malkinson M, Banet C, Weisman Y, Pokamunski S, King R, Drouet $\mathrm{MT}$, et al. Introduction of West Nile virus in the Middle East by migrating white storks. Emerg Infect Dis. 2002;8:392-7.

24. Lvov DK, Butenko AM, Gromashevsky VL, Kovtunov AI, Prilipov AG, Kinney R, et al. West Nile virus and other zoonotic viruses in Russia: examples of emerging-reemerging situations. Arch Virol Suppl. 2004;18:85-96.

25. Bakonyi T, Gould EA, Kolodziejek J, Weissenböck H, Nowotny N. Complete genome analysis and molecular characterization of Usutu virus that emerged in Austria in 2001: comparison with the South African strain SAAR-1776 and other flaviviruses. Virology. 2004;328:301-10.

26. Weissenböck H, Kolodziejek J, Fragner K, Kuhn R, Pfeffer M, Nowotny N. Usutu virus activity in Austria, 2001-2002. Microbes Infect. 2003;5:1132-6.

Address for correspondence: Norbert Nowotny, Zoonoses and Emerging Infections Group, Clinical Virology, Clinical Department of Diagnostic Imaging, Infectious Diseases and Clinical Pathology, University of Veterinary Medicine, Vienna, Veterinärplatz 1, A-1210 Vienna, Austria; fax: 43-1-25077-2790; email: Norbert.Nowotny@vu-wien.ac.at

\title{
Bedside Manners
}

\author{
Christopher Wiseman
}

How little the dying seem to need-

A drink perhaps, a little food,

A smile, a hand to hold, medication,

A change of clothes, an unspoken

Understanding about what's happening.

You think it would be more, much more,

Something more difficult for us

To help with in this great disruption,

But perhaps it's because as the huge shape

Rears up higher and darker each hour

They are anxious that we should see it too

And try to show us with a hand-squeeze.
We panic to do more for them,

And especially when it's your father,

And his eyes are far away, and your tears

Are all down your face and clothes,

And he doesn't see them now, but smiles

Perhaps, just perhaps because you're there.

How little he needs. Just love. More Love.

From In John Updike's Room: New and Selected Poems, by Christopher Wiseman.

Copyright 2005 The Porcupine's Quill. Available from www.amazon.com Reprinted with author's permission. 